\title{
QUALIMETRIC ASSESSMENT OF WAFFLES WITH FILLINGS OF ORGANIC RAW MATERIALS
}

\author{
Alina Tkachenko \\ PhD, Associate Professor \\ alina_biaf@ukr.net \\ Ivan Syrokhman \\ Doctor of technical sciences, professor \\ Department of Commodity Science, Technologies and Food Quality Management \\ Lviv University of Trade and Economics \\ 10 T.-Baranovskoho str., Lviv, Ukraine, 79005 \\ syrokhman@ukr.net \\ Vyacheslav Skrypnyk \\ Doctor of Technical Sciences., Associate Professor \\ Department of Engineering, Equipment and Mathematics ${ }^{2}$ \\ Gabriella Birta \\ Doctor of agricultural sciences, Professor ${ }^{1}$ \\ birta2805@gmail.com \\ Yuriy Burgu \\ PhD, Associate Professor \\ Byrgy@gmail.com \\ ${ }^{1}$ Department of Commodity research, biotechnology, examination and customs \\ ${ }^{2}$ Poltava University of Economics and Trade \\ 3 Kovalia str., Poltava, Ukraine, 36014
}

\begin{abstract}
For improving the amino acid and organoleptic characteristics of floury confectionary products, new recipes of waffles with fillings of natural raw materials "Summer temptation" and "Coco pleasure" have been created. Only organic raw materials were used for both recipes. The composition of waffles "Summer temptation" included: buckwheat flour, reed sugar, creamy butter, dry skimmed milk and sea-buckthorn oil, lemongrass powder. Rice flour, coco sugar, dry coco milk, lemongrass powder were added to the composition of waffles "Coco pressure".

A control sample is waffles "Artek", produced by the traditional recipe. The main difference between the offered samples is in fact that the new waffles are produced of organic raw materials only and contain non-traditional ones in their composition. Wheat flour, lipid base and sugar are replaced in the samples. This paper offers a qualimetric assessment scale for waffles quality and presents assessment results.
\end{abstract}

Keywords: qualimetric assessment, waffles, consumption properties, organoleptic indicators, food value, floury confectionary products.

DOI: $10.21303 / 2504-5695.2020 .001379$

\section{Introduction}

Full-value determination of product quality is possible only by mathematical modeling of a quality indicator. As to food products, a single indicator cannot fully reflect their quality. The complex assessment has an essential advantage that is in using a totality of quality indicators $[1,2]$. The source [3] notes that special attention is paid to numerical quality determination today. Qualimetric measuring mainly consists of two main stages. The first one is measuring of different characteristics (properties) of products mechanical, spatial, electric, magnetic, thermal, chemical composition and so on. The second one is products' quality assessment by determining a quality level, based on obtained results of measuring their correspondent characteristics or properties. There are two methods for assessing products' quality - differential and complex. Products' quality indicators in 
their turn are divided in absolute and relative. The complex method of products' quality measuring was used in this paper [4].

There are scientific data about the fact that an important stage of quality assessment is interrogation of consumers about their ideas on food products quality [5]. Modern European approaches to quality estimation are based on the quality paradigm. Its main statements may be used for both solving tasks of quality improvement and for improving society living conditions. The modern quality conception is oriented on complete satisfaction of consumers' demands [5].

Qualimetry is defined as a science about products' quality measuring [6]. A special feature of the qualimetric method of quality assessment is numerical comparison of a studied product with a standard, either already existent product or one, idealized taking into account modern requirements to nutrition, product-standard. Qualimetric analysis is considered as the most objective method, allowing to chose and to assess a material.

The works $[7,8]$ are devoted to the qualimetric assessment of waffles. But the improvement of the assortment of floury confectionary product and change of priorities in consumers' behavior and requirements condition actualization of group and single quality indicators.

Based on it, the aim of the work is qualimetric assessment of the developed waffles. It allows to analyze consumers' requirements to products' quality and to investigate the new products by the complex quality indicator.

\section{Materials and Methods}

Requirements of the national standard «Waffles. General technical characteristics. Technical conditions: SSU 4033-2018» are taken into account at developing the new products. According to this standard, the following indicators are regulated:

- organoleptic indicators (taste and smell, outlook, color, construction in cut, filling quality);

- physical-chemical indicators (mass share of total sugar, mass share of moisture, alkalinity, mass share of ash).

Safety indicators regulate the content of toxic elements and microbiological indicators.

Taking into account consumers' requirements and real needs as to improving consumption properties of floury confectionary products, the following indicators were considered at forming the complex quality indicator:

- organoleptic properties;

- physical-chemical indicators;

- content of toxic elements;

- microbiological indicators;

- food value;

- energetic value.

Thus, the mathematical model of the complex quality indicator of waffles looks as:

$$
\begin{aligned}
& K_{0}=M_{1}\left(\begin{array}{l}
M_{11} \frac{P_{11}}{P_{11}^{b}}+M_{12} \frac{P_{12}}{P_{12}^{b}}+M_{13} \frac{P_{13}}{P_{13}^{b}}+M_{14} \frac{P_{14}}{P_{14}^{b}}+ \\
+M_{15} \frac{P_{15}}{P_{15}^{b}}+M_{16} \frac{P_{16}}{P_{16}^{b}}+M_{17} \frac{P_{17}}{P_{17}^{b}}+M_{18} \frac{P_{18}}{P_{18}^{b}}
\end{array}\right)+M_{2}\left(M_{21} \frac{P_{21}}{P_{21}^{b}}+M_{22} \frac{P_{22}}{P_{22}^{b}}+M_{23} \frac{P_{23}}{P_{23}^{b}}+M_{24} \frac{P_{24}}{P_{24}^{b}}\right)+ \\
& +M_{3}\left(M_{31} \frac{P_{31}}{P_{31}^{b}}+M_{32} \frac{P_{32}}{P_{32}^{b}}+M_{34} \frac{P_{34}}{P_{34}^{b}}+M_{35} \frac{P_{35}}{P_{35}^{b}}+M_{36} \frac{P_{36}}{P_{36}^{b}}\right)+M_{4}\left(M_{41} \frac{P_{41}}{P_{41}^{b}}+M_{42} \frac{P_{42}}{P_{42}^{b}}+M_{43} \frac{P_{43}}{P_{43}^{b}}+M_{44} \frac{P_{44}}{P_{44}^{b}}\right)+
\end{aligned}
$$

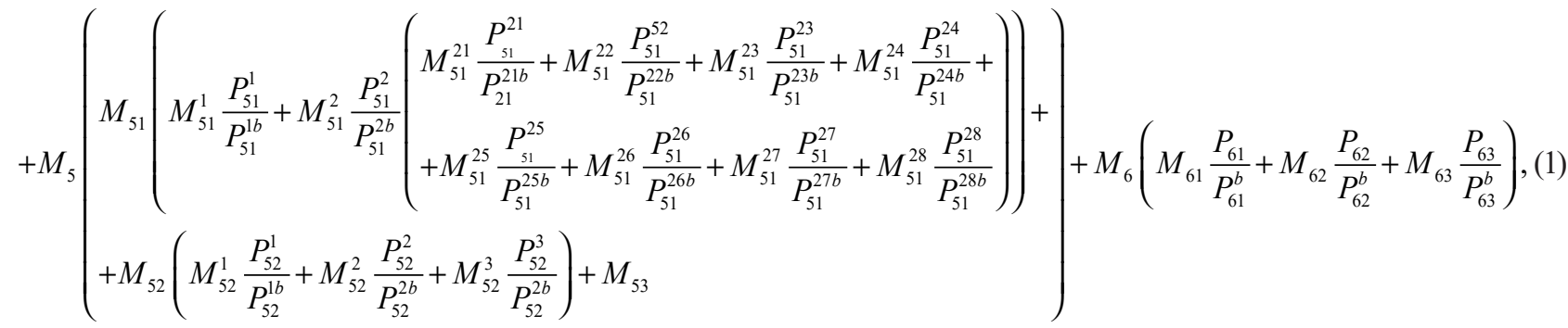


where $K_{0}$ - general quality of the product; $M_{1}, M_{2}, \ldots, M_{n}$ - ponderability coefficients; $P_{1}$ - organoleptic indicators: $\left(P_{11}-\right.$ form; $P_{12}-$ outlook; $P_{13}$ - harmony; $P_{14}-$ color; $P_{15}-$ look in cut; $P_{16}-$ filling quality ; $P_{17}-$ smell; $P_{18}-$ taste); $P_{2}-$ physical-chemical indicators: $\left(P_{21}-\right.$ moisture; $P_{22}-$ soaking, $P_{23}$ - alkalinity; $P_{24}$ - mass share of ash, unsolved in $10 \%$ saline acid solution); $P_{3}-$ the content of toxic elements: $\left(P_{31}-\right.$ plumbum content; $P_{32}$ - cadmium content; $P_{33}-$ arsenic content; $P_{34}-$ mercury content; $P_{35}$ - copper content; $P_{36}-$ zinc content); $P_{4}-$ microbiological indicators: $\left(P_{41}-\right.$ mesophilic aerobic and facultative anaerobic microorganisms; $P_{42}$ - bacteria of the colon bacillus group; $P_{43}-$ pathogenic microorganisms (bacteria of Salmonella genus), $P_{44}$ - fungi, CFU in $1 \mathrm{~g}$ ); $P_{5}$ - food value $\left(P_{51}-\right.$ content of proteins: $\left(P_{51}^{1}-\right.$ content of dispensable amino acids; $P_{51}^{2}-$ content of indispensable amino acids: $P_{51}^{21}-$ lysine content, $P_{51}^{22}$ - isoleucine content, $P_{51}^{23}$ - valine content, $P_{51}^{24}$ - phenylalanine+tyrosine content, $P_{51}^{25}-$ tryptophan content, $P_{51}^{26}-$ methionine+cystine content, $P_{51}^{27}-$ leucine content, $P_{51}^{28}$ - threonine content); $P_{52}$ - fat content; $P_{52}^{1}$ - content of saturated fatty acids; $P_{52}^{2}-$ content of monounsaturated fatty acids; $P_{52}^{3}$ - content of polyunsaturated fatty acids); $P_{53}$ - carbohydrate content; $P_{6}$ - energetic value: $P_{61}$ - number of calories from proteins oxidation; $P_{62}$ - number of calories from lipids oxidation; $P_{63}$ - number of calories from carbohydrates oxidation.

The hierarchic model of the complex quality indicator is presented on Fig. 1.

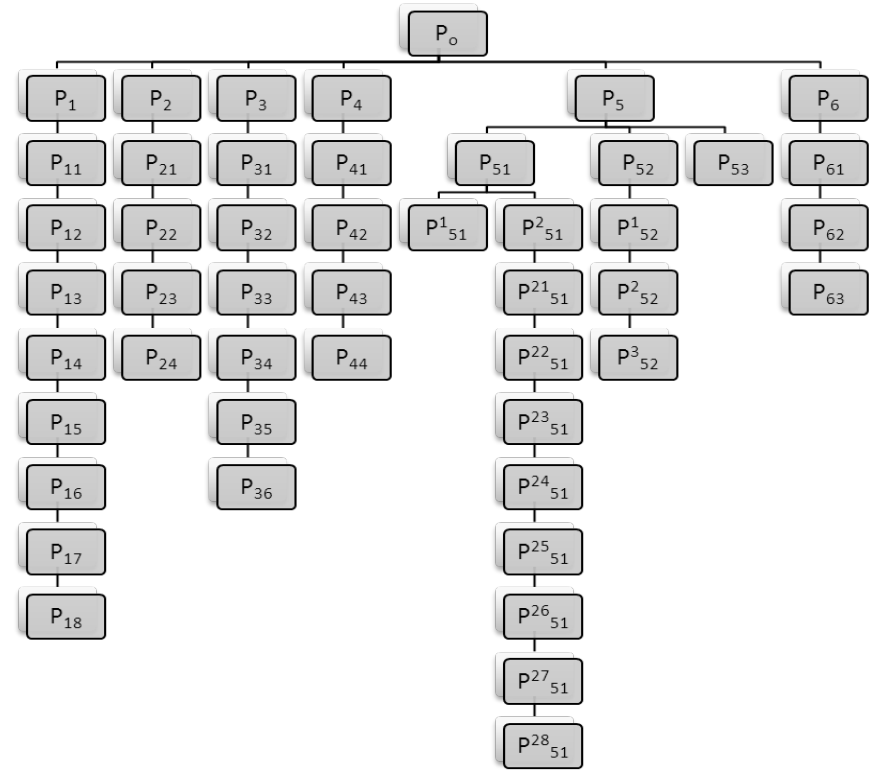

Fig. 1. Hierarchic structure of quality indicators of the waffles with the fillings

Fig. 1 demonstrates the group quality indicators: organoleptic properties; physical-chemical indicators content of toxic elements; microbiological indicators; food value; energetic value. Group quality profiles, formed for each group of products' quality indicators and consisted of studied quality profiles that are numerical values of single quality indicators were determined experimentally. For determining group quality indicators, the studied profiles are compared with basic ones, taking into account correspondent needs of consumers of such products.

\section{Results}

The important stage of the qualimetric assessment is to determine ponderability coefficients of group and single quality indicators of products [9]. In this study, they were determined, based on the method of expert judgments (Table 1).

Ponderability coefficient values for each group quality indicator were determined by the formula:

$$
K_{i}=\sum P_{i y} / y
$$

where $K_{i}$ - ponderability coefficient; $P_{i y}$ - mark of $i$-th indicato by $y$-th expert; $y$ - number of experts. 
Table 1

The assessment results of ponderability coefficients of group quality indicators of the waffles with the fillings of organic raw materials

\begin{tabular}{ccccccc}
\hline No. of expert & $\begin{array}{c}\text { Organoleptic } \\
\text { indicators } \\
\text { (Group P1) }\end{array}$ & $\begin{array}{c}\text { Physical-chem- } \\
\text { ical indicators } \\
\text { (Group P2) }\end{array}$ & $\begin{array}{c}\text { Content of } \\
\text { toxic elements } \\
\text { (Group P3) }\end{array}$ & $\begin{array}{c}\text { Microbiologi- } \\
\text { cal indicators } \\
\text { Group P4) }\end{array}$ & $\begin{array}{c}\text { Food value } \\
\text { (Group P5) }\end{array}$ & $\begin{array}{c}\text { Energetic value } \\
\text { (Group P6) }\end{array}$ \\
\hline 1-st & 0.25 & 0.15 & 0.1 & 0.1 & 0.3 & 0.1 \\
2-nd & 0.35 & 0.05 & 0.2 & 0.2 & 0.1 & 0.1 \\
3-d & 0.15 & 0.1 & 0.05 & 0.2 & 0.3 & 0.2 \\
4-th & 0.3 & 0.1 & 0.2 & 0.1 & 0.25 & 0.05 \\
5-th & 0.2 & 0.15 & 0.2 & 0.15 & 0.25 & 0.05 \\
6-th & 0.25 & 0.05 & 0.15 & 0.1 & 0.35 & 0.1 \\
7-th & 0.25 & 0.1 & 0.15 & 0.15 & 0.25 & 0.1 \\
Sum of points & 1.75 & 0.7 & 1.05 & 1.05 & 1.75 & 0.7
\end{tabular}

The ponderability coefficient values of group quality indicators are presented in Table 2.

Table 2

The ponderability coefficient values of group quality indicators of the waffles with the fillings of organic raw materials

\begin{tabular}{ccc}
\hline No. & Name of group quality indicator & Value of ponderability coefficient (Pi) \\
\hline 1 & Organoleptic indicators (Group P1) & 0.25 \\
2 & Physical-chemical indicators (Group P2) & 0.10 \\
3 & Content of toxic elements (Group P3) & 0.15 \\
4 & Microbiological indicators (Group P4) & 0.15 \\
5 & Food value (Group P5) & 0.25 \\
6 & Energetic vale (Group P6) & 0.10
\end{tabular}

The ponerability coefficient value of each property indicator may have a crucial importance for final qualimetric assessment [10]. According to the results of the expert judgment, most essential are organoleptic indicators and food value. Least essential are physical-chemical indicators and energetic value.

Based on the determination data of the new products' quality, the qualimetric assessment of quality of the developed waffles, based on organic raw materials, was realized. Its results, determined by formula 1, are presented in Table 3 .

So, the organoleptic indicators of the developed products exceed the control sample with coefficients of the group quality indicators 0.21 («Summer temptation») and 0.22 («Coco pleasure»). All samples had the same points by the physical-chemical and microbiological indicators. The food value, especially determined by amino acid, fatty acid, mineral and vitamin composition, differed in the sample "Coco pleasure". It is connected with the fact that the content of indispensable amino acids in the samples essentially increased. The content of saturated fatty acids in both samples decreased almost twice, whereas the content of monounsaturated fatty acids and polyunsaturated fatty acids on the contrary increased. Oleic acid increased in both samples in 1.5 times. Adding the non-traditional raw materials favored the improvement of the mineral and vitamin composition of the waffles. The energetic value decreased in the sample «Summer temptation» by $11 \%$, in the sample «Coco pleasure» - by $14 \%$. But it didn't essentially influence the total result of the group quality indicator.

Thus, the diagram of the complex quality indicators is presented on Fig. 2. 
Table 3

Determination of group quality indicators of the waffles

\begin{tabular}{ccccc}
\hline Name of the group indicator & $\begin{array}{c}\text { Ponderability } \\
\text { coefficient }\end{array}$ & Control & $\begin{array}{c}\text { «Summer } \\
\text { temptation» }\end{array}$ & «Coco pleasure» \\
\cline { 3 - 5 } & & 0.25 & 0.17 & $\begin{array}{c}\text { Value of the group indicator (Pi) taking into account } \\
\text { the ponderability coefficient }\end{array}$ \\
\hline Organoleptic indicators (Group P1) & 0.10 & 0.1 & 0.21 & 0.22 \\
Physical-chemical indicators (Group P2) & 0.15 & 0.12 & 0.1 & 0.1 \\
Content of toxic elements (Group P3) & 0.15 & 0.15 & 0.15 & 0.15 \\
Microbiological indicators (Group P4) & 0.25 & 0.17 & 0.19 & 0.15 \\
Food value (Group P5) & 0.10 & 0.08 & 0.09 & 0.22 \\
Energetic vale (Group P6) & 1 & 0.79 & 0.89 & 0.09
\end{tabular}

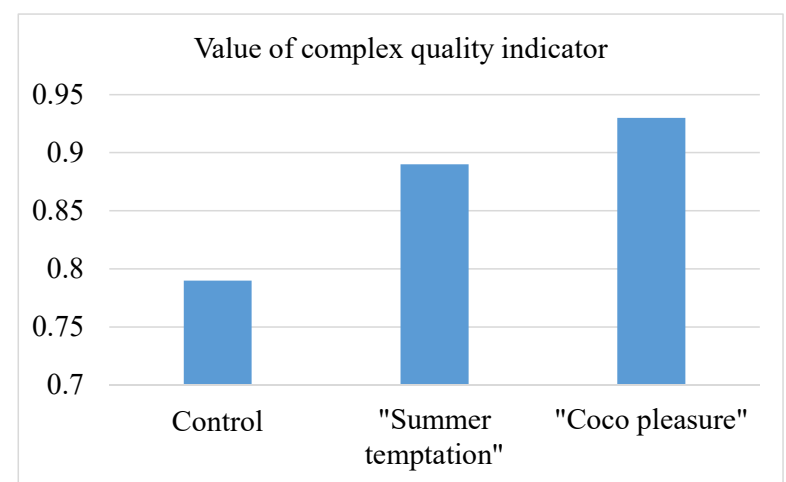

Fig. 2. Complex quality indicators of the waffles with the fatty fillings of organic raw materials

The data of Fig. 1 testify to the fact that the most complex quality indicator is inherent to the sample «Coco pleasure», on the second place - «Summer temptation», the control sample occupies the third place. This result is influenced first of all by the organoleptic indicators of the products that play an also important role for a consumer.

\section{Conclusions}

At forming the complex quality indicator of the waffles, the following indicators were taken into account: organoleptic properties; physical-chemical indicators content of toxic elements; microbiological indicators; food value; energetic value. The ponderability coefficients of the group quality indicators have been established by the method of expert judgments. They are: 0.25 for the organoleptic indicators and food value; 0.15 for the microbiological and toxicological indicators; 0.1 for the physical-chemical indicators and energetic value. The most complex quality indicator is inherent to the sample «Coco pleasure» (0.93), on the second place - «Summer temptation» (0.89), the control sample occupies the third place $(0.79)$.

The main advantage of this study is the fact that the method of qualimetric assessment of waffles quality gained further development. Due to the method of expert judgment, the coefficients of the group quality indicators that influence the complex quality parameter of the products were taken into account. A shortcoming of the conducted study is the absence of scientific researches as to automation of waffles qualimetric assessment.

Author's previous studies were devoted to projecting new cakes, biscuits, pancake, based on organic raw materials. This study is a continuation of the research topic as to widening the assortment of floury confectionary products.

Further studies are planned to be devoted to studying a quality change of developed products at storage. 


\section{References}

[1] Mashta, N. (2011). The modelling features of complex quality index of melted cheese products of functional direction. Visnyk Lvivskoi komertsiynoi akademiyi. Seriya tovaroznavcha, 12, 108-112.

[2] Kovbasa, V. M., Myronova, N. H., Dorokhovych, A. M., Terletska, V. A., Diachuk, O. V. (1998). Kvalimetrychna otsinka yakosti sukhykh snidankiv. Kharchova promyslovist, 43-44, 25-30

[3] Van Rijswijk, W., Frewer, L. J. (2008). Consumer perceptions of food quality and safety and their relation to traceability. British Food Journal, 110 (10), 1034-1046. doi: https://doi.org/10.1108/00070700810906642

[4] Chorna, T., Yanushkevych, D., Afanasieva, V. (2018). Modern Aspects of Safety Assessment of Foodstuff. Path of Science, 4 (4), 4001-4012. doi: https://doi.org/10.22178/pos.33-7

[5] Bergan, H. (1990). Extending the reach of the quality improvement paradigm. Quality Progress, 23 (5), 51-52.

[6] Azgaldov, G. G., Kostin, A. V. (2011). Applied qualimetry: its origins, errors and misconceptions. Benchmarking: An International Journal, 18 (3), 428-444. doi: https://doi.org/10.1108/14635771111137796

[7] Lozova, T. (2014). Improved consumer properties of wafers using non-traditional raw materials. Eastern-European Journal of Enterprise Technologies, 2 (12 (68)), 108-113. doi: https://doi.org/10.15587/1729-4061.2014.23356

[8] Pakhomova I., Tkachenko A. (2017). The Impact of Packaging on Quality Preservation of New Wafers and the Possibility of Predicting Shelf Life. Towaroznawcze Problemy Jakości, 4, 91-102.

[9] Alpaslan, M., Hayta, M. (2006). The effects of flaxseed, soy and corn flours on the textural and sensory properties of a bakery product. Journal of Food Quality, 29 (6), 617-627. doi: https://doi.org/10.1111/j.1745-4557.2006.00099.x

[10] Boiko, T. H, Hrynevych, B. Yu. (2011). Otrymannia koefitsientiv vahomosti dlia kilkisnoi otsinky yakosti produktsiyi za skladovymy nepevnosti otsiniuvannia. Vymiriuvalna tekhnika i metrolohiia, 72, 111-116. 